\title{
The Red Thread: The Passaic Textile Strike
}

Jacob A. Zumoff

New Brunswick: Rutgers University Press, 2021

248 pages

ISBN: 9781978809895

DOI: https://doi.org/10.14713/njs.v8i1.274

In The Red Thread, Jacob A. Zumoff offers a fresh perspective and a "synthetic" history of the 1926 textile workers strike in Passaic, New Jersey. The Passaic strike is certainly an underexamined chapter of American labor history, and the conflict deserves scholarly attention. The unrest took place in the latter half of the 1920s, the so-called "lean years" of American labor in which mass strikes were rare, especially compared to the tumultuous postwar era. The late twenties also saw the continued rise of notorious far-right movements like the Ku Klux Klan. The existence, then, of a yearlong strike of more than 10,000 textile workers, led, as Zumoff definitively shows, by the Communist Party, provides an interesting and necessary corrective of our common historical understanding of the Jazz Age.

Zumoff's work is at its best when he places the reader inside the homes and workshops of Passaic's workers. Mill owners exploited their largely Eastern and Southern European immigrant workforce (a small number of African Americans also worked in the mills), packing them into squalid conditions for long hours with little pay. The National Consumers League general secretary at that time, Florence Kelley, described rooms of deafening machinery without light, ventilation, and adequate bathrooms. Infant mortality was $50 \%$ higher in Passaic than the rest of the state, Zumoff reveals. Mill owners had successfully foiled substantive union drives by fragmenting their employees by nationality, relying on the influence of anti-union religious leaders (though several Catholic priests and rabbis supported unionization), and by cultivating relationships with local politicians and police. After announcing a $10 \%$ reduction in wages, however, mill owners could no longer stymie discontent on their production lines. 
Zumoff's microstudy of industrial work and organizing is rich and nuanced. His central narrative thread is the leading role of the Communist Party. Zumoff aptly demonstrates how the party dispatched to Passaic talented and driven organizers like Albert Weisbord. A child of Russian Jews, a devoted Marxist, and a Harvard-educated lawyer, Weisbord kept up the strike in the face of mass arrests and patrolmen's clubs. Historians of American labor and movements will take a particular interest in Zumoff's discussion of the party's fundraising initiatives and its use of new forms of media. The Communists had funded the production of the silent film The Passaic Textile Strike, and Alfred Wagenknecht, the party's "champion money-raiser," screened it nationwide. He raised the modern equivalent of more than $\$ 400,000$ for the strike fund, helping underwrite soup kitchens, bail bonds, and childcare centers. Zumoff argues that even officers of the rigidly anticommunist United Textile Workers (UTW) begrudgingly acknowledged the party's fundraising prowess, with UTW secretary Sarah Conboy calling Wagenknecht a "financial genius" (110).

Occasionally, Zumoff's intense focus on the Communist Party's role obscures the Red Thread's overall relevance to broader themes in twentieth-century American history. While scholars of American communism will undoubtedly enjoy Zumoff's long discussion of intra-party fracases over forming United Front committees instead of traditional unions, readers unversed in Marxist-Leninist theory might question this emphasis. Relatedly, Zumoff makes no secret that he is "sympathetic to the politics of early American Communists" (8). A few times this clear sympathy prohibited what might have been a more nuanced interpretation of the strike.

As Zumoff argues, the stoppage's dramatic beginning shocked American labor and its allies - many rallied to aid the picketing workers. Yet in his telling, these supposed allies cared more about removing the strike's Communist leadership than winning demands. Zumoff does indeed demonstrate that individuals - like reformer (and future New York City Family Court 
judge) Justine Wise Polier; her father, Rabbi Stephen Wise; labor lawyer Frank P. Walsh; New Jersey Governor Frank A. Moore; and Senators William Borah, Burton K. Wheeler, and Robert La Follette Jr.-made Communist withdrawal from strike leadership a precondition to offering any kind of arbitration. So, too, did American Federation of Labor president William Green, and Amalgamated Clothing Workers' president Sidney Hillman. Zumoff takes clear issue with the leadership of the AFL-aligned UTW, whom he accused of being "hostile" to the strike and of “turning their backs" on Passaic's workers (51-53). "In Passaic the Communist Party fought for the entire working class as the rest of the labor movement retreated," Zumoff writes (156).

Yet Zumoff might have more fully interrogated why those sympathetic to the strike universally disapproved of its Communist leadership. Often, he conflates anti-communism with class collaborationism and being generally hostile to worker interests. This was not always the case. While historically the UTW may have been narrowly focused on bringing in more skilled and native-born textile workers, its leadership was hardly indifferent to the plight of the unorganized. Elected as UTW president in 1921, Thomas F. McMahon was something of a progressive - he maintained a close relationship with noted radical A. J. Muste and sent several of UTW's members to the famed Brookwood Labor College. Only a year into his tenure, McMahon helped lead a New England-wide textile strike against a $20 \%$ reduction in wages that involved tens of thousands of workers. After many grueling months on the line, most of these workers avoided cuts but gained little else. This was ultimately the same deal the UTW negotiated in Passaic after absorbing those workers at the end of $1926 .{ }^{1}$

\footnotetext{
${ }^{1}$ Thomas F. McMahon, "The President's Column," The Textile Worker (April 1923), 11-12; Leilah Danielson, American Gandhi: A. J. Muste and the History of Radicalism in the Twentieth Century (Philadelphia: University of Pennsylvania Press, 2014), 81-82; Steve Fraser, Labor Will Rule: Sidney Hillman and the Rise of American Labor (New York: Free Press, 1991), 155-156; Leonard E. Tilden, "New England Textile Strike," Monthly Labor Review (May 1923), 13-36.
} 
Perhaps McMahon, Green, Hillman, and other labor leaders disapproved of Weisbord and his United Front committee not out of reflexive anti-communism, but because they had legitimate concerns and learned experiences. The 1922 strike showed how difficult it was for shops with established unions to fight back in an industry rapidly moving toward automation and displacement to Southern states with no union protections. Four years later Passaic workers had walked out in the harsh winter months with no established strike fund in a city notorious for its union busting. Weisbord was an unquestionably talented organizer, but his political affiliation served as a lightning rod, allowing the mill owners to remain recalcitrant. Few Americans beyond the roughly 10,000 members of the Communist Party sympathized with Marxism-Leninism. Managers, therefore, could afford to stall negotiations and ultimately whittle down the strikers' demands.

The strike ended in a strategic defeat. It took labor another 20 years to organize the region's mills, and most would stop production by 1960. Still, in 1926, New Jersey's textile workers fought automation and outsourcing. The foreign-born, Jewish, and Black picketers faced racist and nativist attacks, including threats from the Ku Klux Klan. These convulsions of capital, class, gender, ethnicity, and race still reverberate today. Zumoff has provided the field with an excellent entry point to rediscover this neglected crucial moment in time, not just for northern New Jersey, but the world.

\section{Andreas Meyris \\ George Washington University}

